\title{
IAMJ
}

INTERNATIONAL

AYURVEDIC

MEDICAL JOURNAL

\section{A COMPARATIVE CLINICAL STUDY ON MATRA BASTI WITH SAHACHARADI TAILA AND VYOSADI TAILA IN GRIDHRASI W.S.R TO SCIATICA}

\author{
Vasudev $\mathbf{R}^{1}$, Swathi S Deshpande ${ }^{2}$ \\ ${ }^{1}$ PG Scholar, ${ }^{2}$ Professor \& HOD, \\ Department of P.G Studies in Panchakarma, Karnataka Ayurveda Medical College and \\ Hospital, Mangalore, D.K District, Karnataka, India
}

Corresponding Author: vasudevr0@gmail.com

\section{https://doi.org/10.46607/iamj1908102020}

(Published online: October 2020)

Open Access

(C) International Ayurvedic Medical Journal, India 2020

Article Received: 27/09/2020 - Peer Reviewed: 29/09/2020 - Accepted for Publication: 04/10/2020

\section{Check for updates}

\section{ABSTRACT}

Gridhrasi is one among Vatajananatmaja Vikara characterized by Sthabdhata, Ruk, Toda which radiates from buttock region, lumbar region, thigh, knee, calf muscles and legs. Gridhrasi is of two types viz Vataja and Vata Kaphaja Gridhrasi. Vataja Gridhrasi is characterized by severe pain and Vata Kaphaja Gridhrasi has symptoms viz Tandra, Gaurava and Aruchi. The signs and symptoms of Gridhrasi can be correlated to sciatica of modern medicine. Sciatica is characterized by constant aching pain felt in lumbar region which may radiate to the buttock, thigh, calf and foot and pain is experienced along the sciatic nerve pathway. It is a common condition with lifetime incidence varying from $13 \%$ to $40 \%$. Matra Basti is indicated in diseases caused by vitiated Vata Doshas and thus considered as one of the treatments for Gridhrasi. It was a comparative clinical study with a pre and post design in 40 patients who were diagnosed with Gridhrasi, were assigned into 2 groups of 20 patients each randomly. After examination MatraBasti had given for group A with Vyoshadi Taila and group B with Sahacharadi Taila after Sthanika Abhyanga and Nadisweda with respective oil for 7 days. The assessment criteria were noted before and after treatment and on followup. Among the subjective and objective parameters, Group A showed better reduction 51.47\% in Ruk, Sthambha, Toda, Gaurava, active and passive SLR test, Bragard's test and Lumbar movements. Group B does not have statistically significant over Gaurava, left lateral flexion and rotation to 
leave. Showed reduction $40.49 \%$ in Ruk, Sthambha, Toda active and passive SLR test and lumbar movement. Hence it can be concluded that MatraBasti with Vyosadi Tailam is having more effect on symptoms of Gridhrasi and shows long lasting result.

Keywords: Gridhrasi, MatraBasti, Sahacharadi Taila, Sciatica, Vyoshadi Taila.

\section{INTRODUCTION}

Ayurveda is the most ancient system of medicine which originated thousands of years back, is the only discipline that proposed with the dual objects of keeping each and every person healthy as well as to root out disease.

Basti therapy is said to be the best therapy for pacifying aggravated Vata Dosha. Hence, it is considered as Ardha Chikitsa. By administration of medicine through rectal route, it reaches Nabhi (umbilical region), Kati (lumbar region), Parshwa (flanks) and Kukshi (abdominal region) and does the Vilodana of Dosha and Snehana of body, thus morbid Dosha are eliminated along with faeces ${ }^{1}$. Anuvasana Basti is a type of Basti where, Sneha Dravya are administered through ano rectal route. Anuvasana Basti believed to nourish the body and increases Bala (strength) and Varna (complexion) ${ }^{2}$. Matra Basti is a type of Anuvasana Basti in which the Sneha is administered in lowest dosage i.e. Quarter (1/4th) quantity of Sneh$a_{B a s t i}{ }^{3}$. The dose is equal to the dose of Hrisva Snehapana. It is indicated in people debilitated due to heavy work, exercise, lifting heavy weight and in persons afflicted by diseases due to Vata Dosha. It increases Bala, helps in easy and comfortable evacuation of Mala and pacifies Vata Dosha ${ }^{4}$.

Gridhrasi is one among Vataja Nanatmaja Vikara ${ }^{5}$ characterized by Sthabdhata (stiffness), Vedana (pain), Toda (pricking sensation) which radiates from buttock region, lumbar region, thigh, knee, calf muscles and legs. Gridhrasi is of two types viz Vataja and Vata Kaphaja Gridhrasi. Vataja Gridhrasi is characterized by severe pain and Vata Kaphaja Gridhrasi has symptoms viz Tandra (drowsiness), Gaurava (heaviness of body) and Aruchi (anorexia) ${ }^{6}$. Sciatica is characterized by constant aching pain felt in lumbar region which may radiate to the buttock, thigh, calf and foot $^{7}$ and pain is experienced along the sciatic nerve pathway. This term is more specifically used to denote nerve dysfunction caused by compression of one or more lumbar or sacral nerve roots from a spinal disc herniation. The pain is characteristically of a shooting type quickly travelling along a course of the nerve $^{8}$. Thus, Sciatica may be readily correlated to Gridhrasi of Ayurveda parlance. Basti Karma, Agni Karma and Siravyadha are considered as the choices of treatment in managing Gridhrasi ${ }^{9}$. Basti Karma plays a vital role in pacifying the aggravated Vata Dosha in Gridhrasi and thus yield good relief from the symptoms of it. Matra Basti is indicated in diseases caused by vitiated Vata Doshas and thus may be considered as one of the treatments for Gridhrasi. Ingredients of Sahacharadi Taila ${ }^{10}$ are Sahachara, Ksheera and Tila Taila. due to Snigdha and Ushna Guna it acts as Vata and Kapha Dosha hara. And it is very effective in Adha Kaya Vata Rogas.

The ingredients in Vyosadi Taila ${ }^{11}$ are Vyosa, Pippalimoola, Rasna, Vastimadhu, Saindhava, Devadaru, Amrta, Kusta, Vajigandha, Vaca, and Sati and it is indicated in Gridhrasi. This oil is prescribed in the form of intake, enema, and abhyanga.

Hence, a comparative study is undertaken among two groups of Matra Basti, where one group is treated with Sahacharadi Taila and other with Vyosadi Taila to ascertain the effect of either of the treatment modality in management of Gridhrasi

\section{Aim and Objectives}

1. To evaluate the effect of Sahacharadi Taila Matra Basti in the management of Gridhrasi (sciatica).

2. To evaluate the effect of Vyoshadi Taila Matra Basti in the management of Gridhrasi (sciatica).

3. To compare the effect of Sahacharadi Taila and Vyoshadi Taila Matra Basti in the management of Gridhrasi (sciatica). 


\section{Methodology}

\section{Method of Collection of Data}

Sample Size - 40 patients fulfilling the diagnostic and inclusion criteria of Gridhrasi (sciatica) for the study and randomly assigned into 2 equal groups Vyosadi Tailam Matra Basti (group A) Sahacharadi Taila Matra Basti (group B).

\section{Diagnostic Criteria}

- Ruk (Pain)on Sphik, Kati, Prishta, Uru, Janu, Jangha and Padaparyanta vedana

- Toda (Pricking pain)

- Stambha (Stiffness)

- Gourava (Heaviness)

- Positive SLR test

\section{Inclusion Criteria}

- Patients with symptoms of radiating pain from Sphik (buttock) and Kati (lumbar region) to Prishta (back), Uru (Thigh). Janu (knee), Janga (calf region) and Pada (feet).

- Patients between age group 20-60 years irrespective of gender and socio-economic status

- Patients who are fit for Sneha Basti Karma.

\section{Exclusion Criteria}

- Traumatic, Infective, Neoplastic, Degenerative Conditions of Spine.

- Congenital Spinal Anomalies.

- Pregnancy and Lactating Women.

- Patient with chronic systemic diseases.

\section{Study Design}

- Patients were assigned into two groups consisting minimum of twenty patients each group fulfilling the inclusion criteria.

\section{Posology}

- Group A (Vyosadi Tailam Matra Basti) - Patients of this group were administered Matra Basti with Vyosadi Taila in dose of $72 \mathrm{ml}$ for 7 days

- Group B (Sahacharadi Tailam Matra Basti) Patients of this group were administered Matra Basti with Sahacharadi Taila in dose of $72 \mathrm{ml}$ for 7 days.

Intervention: Treatment procedure of Matra Basti. Poorva Karma: Abhyanga is done with Vyosadi Taila for Group A and Sahacharadi Tailam for Group B followed by Nadi Sweda. Patient is advised to have Light
Diet, Patient is asked to evacuate bowel and bladder, Patient is made to lie in the left lateral position with the right leg flexed.

Pradhana Karma: The Tip of the catheter is smeared with oil. The anal orifice is lubricated with oil. The catheter is then introduced into the anal canal till 4- 6 inches. When all the oil is pushed into the rectum, the catheter is gently pulled out.

Paschath Karma: Sphik Thadana is done. Patient is made to lie on supine position. Patient is made to rise the legs by flexing the hip 3-4 times.

\section{Study Duration:}

- 1-7 $7^{\text {th }}$ day: Mathra Basti is given

- 7 days followed by Parihara Kala of 14 days

- Follow up after 21 days

\section{Assessment Criteria}

Group A - Patients were assessed before treatment and after treatment and on the day of follow up.

Group B - Patients were assessed before treatment and after treatment and on the day of follow up.

\section{Subjective Parameters}

- Ruk (Radiating pain)

- Stamba (Stiffness)

- Toda (Pricking sensation)

- Gaurava (Heaviness)

Objective Parameters

- Straight Leg Raising Test

- Bragard's test

\section{Investigations}

Blood Routine Examination (Complete Blood Count, S. Creatinine, S. Uric acid, RA factor, Random Blood Sugar).

\section{Statistical Analysis}

For the statistical analysis, the data obtained in both the groups were recorded, presented in tables, diagrams and graphs. The following statistical tests are used for assessment of parameters:

- Assessment of parameters within the group (after treatment and after follow up) - Wilcoxon sign rank test.

- Assessment of parameters between the groups Mann-Whitney U test.

The corresponding $\mathrm{p}$ value was noted and obtained results were interpreted as follows: 
- For $\mathrm{p}$ value $>0.05$ - interpreted as no significant.

- For $\mathrm{p}$ value $<0.05$ - interpreted as significant.

\section{Observations and Results}

The observations give a detail descriptive statistical analysis about all the 40 patients suffering from
Gridhrasi according to their Age, Sex, Religion, Education, Socioeconomic status, Marital status, Occupation, Vyayama, Duration of illness, Mode of action, Course of disease, Ahara, Prakrithi, Lakshanas.

\section{Results}

\section{Statistical analysis of Subjective and Objective parameters}

\begin{tabular}{|c|c|c|c|c|c|c|c|c|c|}
\hline \multirow[t]{2}{*}{ Group } & \multicolumn{4}{|c|}{ Mean score } & \multirow[t]{2}{*}{$\%$} & \multirow[t]{2}{*}{ S.D $( \pm)$} & \multirow[t]{2}{*}{ S.E $( \pm)$} & \multirow[t]{2}{*}{ Wilcoxon Z Value } & \multirow[t]{2}{*}{ p valuc } \\
\hline & BT & & & BT-AT & & & & & \\
\hline \multirow[t]{2}{*}{ Group A on Ruk } & \multirow[t]{2}{*}{6.95} & AT & 3.45 & 3.50 & 50.36 & 1.051 & 0.241 & 3.92 & $<0.05$ \\
\hline & & $\mathrm{AF}$ & 2.90 & 4.05 & 58.27 & 0.945 & 0.217 & 3.92 & $<0.05$ \\
\hline \multirow[t]{2}{*}{ Group B on Ruk } & \multirow[t]{2}{*}{6.95} & AT & 3.70 & 3.25 & 46.76 & 0.851 & 0.195 & 3.91 & $<0.05$ \\
\hline & & $\mathrm{AF}$ & 3.45 & 3.50 & 50.36 & 0.946 & 0.217 & 3.92 & $<0.05$ \\
\hline \multirow[t]{2}{*}{ Group A on Stamba } & \multirow[t]{2}{*}{1.85} & AT & 0.95 & 0.90 & 48.65 & 0.447 & 0.103 & 3.62 & $<0.05$ \\
\hline & & $\mathrm{AF}$ & 0.85 & 1.00 & 54.05 & 0.562 & 0.129 & 3.62 & $<0.05$ \\
\hline \multirow[t]{2}{*}{ Group B on Stamba } & \multirow[t]{2}{*}{1.80} & AT & 1.20 & 0.60 & 33.33 & 0.681 & 0.156 & 2.80 & $<0.05$ \\
\hline & & $\mathrm{AF}$ & 1.20 & 0.60 & 33.33 & 0.681 & 0.156 & 2.80 & $<0.05$ \\
\hline \multirow[t]{2}{*}{ Group A on Toda } & \multirow[t]{2}{*}{2.05} & AT & 1.15 & 0.90 & 43.90 & 0.788 & 0.181 & 3.18 & $<0.05$ \\
\hline & & $\mathrm{AF}$ & 1.10 & 0.95 & 46.34 & 0.826 & 0.189 & 3.18 & $<0.05$ \\
\hline \multirow{2}{*}{ Group B on Toda } & \multirow[t]{2}{*}{2.35} & AT & 1.50 & 0.85 & 36.17 & 0.587 & 0.135 & 3.40 & $<0.05$ \\
\hline & & $\mathrm{AF}$ & 1.50 & 0.85 & 36.17 & 0.587 & 0.135 & 3.40 & $<0.05$ \\
\hline \multirow[t]{2}{*}{ Group A on Gaurava } & \multirow[t]{2}{*}{1.45} & AT & 0.75 & 0.70 & 48.28 & 0.470 & 0.108 & 3.29 & $<0.05$ \\
\hline & & $\mathrm{AF}$ & 0.60 & 0.85 & 58.62 & 0.671 & 0.154 & 3.29 & $<0.05$ \\
\hline \multirow[t]{2}{*}{ Group B on Gaurava } & \multirow[t]{2}{*}{1.10} & AT & 0.90 & 0.20 & 18.18 & 0.410 & 0.094 & 2.00 & $>0.05$ \\
\hline & & $\mathrm{AF}$ & 0.85 & 0.25 & 22.73 & 0.550 & 0.126 & 2.00 & $>0.05$ \\
\hline Group A on SLR Active Right Leg & 1.70 & AT & 1.10 & 0.60 & 35.29 & 0.503 & 0.115 & 3.05 & $<0.05$ \\
\hline & & $\mathrm{AF}$ & 1.05 & 0.65 & 38.24 & 0.587 & 0.135 & 3.06 & $<0.05$ \\
\hline Group B on SLR Active Right Leg & 1.75 & AT & 1.10 & 0.65 & 37.14 & 0.671 & 0.154 & 2.93 & $<0.05$ \\
\hline & & $\mathrm{AF}$ & 1.10 & 0.65 & 37.14 & 0.671 & 0.154 & 2.93 & $<0.05$ \\
\hline Group A on SLR Active Left Leg & 2.00 & AT & 1.05 & 0.95 & 47.50 & 0.605 & 0.139 & 3.51 & $<0.05$ \\
\hline & & $\mathrm{AF}$ & 0.95 & 1.05 & 52.50 & 0.686 & 0.157 & 3.52 & $<0.05$ \\
\hline Group B on SLR Active Left Leg & 2.15 & AT & 1.30 & 0.85 & 39.53 & 0.671 & 0.154 & 3.29 & $<0.05$ \\
\hline & & $\mathrm{AF}$ & 1.30 & 0.85 & 39.53 & 0.671 & 0.154 & 3.29 & $<0.05$ \\
\hline Group A on SLR Passive Right Leg & 1.10 & AT & 0.80 & 0.30 & 27.27 & 0.470 & 0.108 & 2.2 & 0.80 \\
\hline & & $\mathrm{AF}$ & 0.65 & 0.45 & 40.91 & 0.510 & 0.117 & 2.66 & 0.65 \\
\hline Group B on SLR Passive Right Leg & 1.25 & AT & 0.90 & 0.35 & 28.00 & 0.489 & 0.112 & 2.36 & $<0.05$ \\
\hline & & $\mathrm{AF}$ & 0.90 & 0.35 & 28.00 & 0.489 & 0.112 & 2.36 & $<0.05$ \\
\hline Group A on SLR Passive Left Leg & 1.35 & AT & 0.80 & 0.55 & 40.74 & 0.510 & 0.117 & 2.93 & $<0.05$ \\
\hline & & $\mathrm{AF}$ & 0.80 & 0.55 & 40.74 & 0.510 & 0.117 & 2.93 & $<0.05$ \\
\hline Group B on SLR Passive Left Leg & 1.35 & AT & 0.90 & 0.45 & 33.33 & 0.510 & 0.117 & 2.66 & $<0.05$ \\
\hline & & $\mathrm{AF}$ & 0.90 & 0.45 & 33.33 & 0.510 & 0.117 & 2.66 & $<0.05$ \\
\hline Group A on Bragard's Right Leg & 0.90 & AT & 0.40 & 0.50 & 55.56 & 0.513 & 0.118 & 2.80 & $<0.05$ \\
\hline & & $\mathrm{AF}$ & 0.35 & 0.55 & 61.11 & 0.510 & 0.117 & 2.93 & $<0.05$ \\
\hline Group B on Bragard's Right Leg & 0.70 & AT & 0.40 & 0.30 & 42.86 & 0.470 & 0.108 & 2.20 & $<0.05$ \\
\hline & & $\mathrm{AF}$ & 0.40 & 0.30 & 42.86 & 0.470 & 0.108 & 2.20 & $<0.05$ \\
\hline Group A on Bragard's Left Leg & 0.90 & AT & 0.45 & 0.45 & 50.00 & 0.510 & 0.117 & 2.66 & $<0.05$ \\
\hline & & $\mathrm{AF}$ & 0.45 & 0.45 & 50.00 & 0.510 & 0.117 & 2.66 & $<0.05$ \\
\hline Group B on Bragard's Left Leg & 1.35 & AT & 0.75 & 0.60 & 44.44 & 0.503 & 0.115 & 3.05 & $<0.05$ \\
\hline & & $\mathrm{AF}$ & 0.75 & 0.60 & 44.44 & 0.503 & 0.115 & 3.05 & $<0.05$ \\
\hline
\end{tabular}




\section{Comparative results of Signs and Symptoms of Group-A and Group-B.}

\begin{tabular}{|l|l|l|l|l|l|}
\hline Signs and Symptoms & Group A (Mean Score) & $\begin{array}{l}\text { Group B } \\
\text { (Mean Score) }\end{array}$ & Z-Value of Mann Whitney & U Value & P Value \\
\hline Ruk & 4.43 & 4.70 & 0.87 & 167.00 & $>0.05$ \\
\hline Sthamba & 1.22 & 1.40 & 1.16 & 156.50 & $>0.05$ \\
\hline Toda & 1.43 & 1.78 & 2.10 & 121.50 & $<0.05$ \\
\hline Gaurava & 0.93 & 0.95 & 0.29 & 188.50 & $>0.05$ \\
\hline SLR Active Right Leg & 1.28 & 1.32 & 0.04 & 198.00 & $>0.05$ \\
\hline SLR Active Left Leg & 1.33 & 1.58 & 1.16 & 156.50 & $>0.05$ \\
\hline SLR Passive Right Leg & 0.85 & 1.02 & 1.17 & 173.00 & $>0.05$ \\
\hline SLR Passive Left Leg & 0.98 & 1.05 & 0.12 & 195.00 & $>0.05$ \\
\hline Bragard's Right Leg & 0.55 & 0.50 & 0.33 & 187.00 & $>0.05$ \\
\hline Bragard's Left Leg & 0.60 & 0.95 & 1.59 & 140.50 & $>0.05$ \\
\hline
\end{tabular}

Comparative analysis of the overall effect of the treatments in both the groups was done by statistically with Mann Whitney test. The test shows that the treatment is significant in Group A when compared to Group B. Group A overall result is $51.47 \%$ and Group B overall result is $40.49 \%$.

\section{Comparative results of Group A and Group B}

\begin{tabular}{|l|l|l|l|l|l|l|}
\hline Group A & Group B & Mean Difference & SE $( \pm)$ & Z-Value of Mann Whitney & U Value & P value \\
\hline 51.47 & 40.49 & 10.98 & 3.67 & 2.85 & 94.00 & $<0.05$ \\
\hline
\end{tabular}

\section{DISCUSSION}

Discussion on Disease: In the modern era due to the sedentary lifestyle more people are become victims of Vataja diseases which effect directly or indirectly to the loco motor system. Gridhrasi is one among the 80 types of Vata Vyadhis. Gridhrasi is characterized by shola starting from Sphik and radiates through Kati, Prista, Uru, Janu, Janga and Pada. Associated with Sthamba, Ruk, Toda and Spandana. And if it is associated with Kapha, it shows the symptoms like Tandra, Gaurava and Arochaka. Due to the Nidanas Vata get obstructed by Kapha, Ama etc. which leads to Margavarana Janya Samprapthi of Gridhrasi. Agantuja factors are considered as an important cause of Gridhrasi. These vitiated Dosha effects on Kandaras of lower limb on which the movements on affected leg depends. When this Kandara is affected there will be pain through its root. The signs and symptoms of Gridhrasi can be correlated to sciatica of modern medicine. Sciatica is caused due to the compression or irritation of sciatic nerve, the injury to the sciatic nerve and its branches results in sciatica.

Discussion on Karma: Matra Basti is a type of Sneha Basti in which the drug administration is minimal in quantity and can be administered irrespective of Pathya and Apathya. Guda is the moola of Sharira and is rich in Siras, which provides nutrition to whole body. Drugs in the Pakvashaya will absorb through these Siras and circulates all over the body and act wherever required. Basti is administered through Guda and which enters in Pakvashaya and pacifies the Vata Dosha in its main Sthana and expels Kapha, Pitta, Mutra and Mala. With its potency it reaches all over the body to perform its action. Even though Basti pacifies Vata Dosha it has an effect over pitta and Kapha also, and in Vata it mainly acts on Apana and Samana Vayu. In Ayurvedic texts, there are different methods for treatment of Gridhrasi has been explained some of them are effective, safe, simple, affordable, and can be done in OPD bases.

Discussion on Drug: Vyoshadi Taila: Vyoshadi Taila is explained in Vatavyadhi Chikitsa of Vrindamadhava where there is a direct indication for Gridhrasi. The drugs used in this Taila are Vyosh, Pippalimoola, Rasna, Madhuka, Saindhava Lavana, Devadaru, Amrta, Kustavajigandha, Vacha, and Shati, where most of them are Vata Kaphahara in nature. 
This oil is prescribed for using in the form of Paana, Basti, and Abhyanga.

Sahacharadi Taila: Sahachara Taila is mentioned in Ashtanga Hrudaya. It has Ushna Virya and it act as Vata and Kapha Dosha hara. It is very effective in Adha Kaya Vatarogas. The drugs used in this Taila are Sahachara, Ksheera and Tila Taila.

Discussion on Results: The effect of treatment is based on the basis of statistical evaluation of the subjective and objective criteria like Ruk, Toda, Sthamba, Gaurava, SLR test, and Bragard's test on BT (0 days), AT (7th day) and AF (21st day) of treatment in both groups as well as comparatively were computed by grading and finally, the overall effect of the treatment was statistically analysed from the data available for significance. The obtained results were considered as insignificant if $\mathrm{P}>0.05$, significant if $\mathrm{P}<0.05$.

Discussion on Probable Mode of Action: The Moolasthana of Vata i.e. Pakwashaya will get Mrudutwa by Sneha and Swedana which will facilitate the alleviation of Vata disorder in the body, and it also help for the better retention of Basti Dravya. The alleviation of clinical features of Vata pretending to Ruk, Toda etc. when Snehana and Swedana are adopted properly. The movement of the limb will increase i.e. as a dry wood can be slowly bent as desired by the application of Snehana and Swedana similarly even curved or stiffed limb can bring back into normalcy by the administration of Snehana and Swedana. The Basti medicine can percolate and cross the barrier of an ileocaecal valve which is a door between the end of the ileum (last part of the small intestine, where it enters the large intestine) and caecum (first part of the colon or large intestine). The Basti Dravya reaches the level of the stomach, duodenum and ileum (parts of the small intestine) wherein the active principles of the Basti Dravya are absorbed and made use of. The Veerya of Basti is conveyed to Apana and then Samana Vata which may regulate the function of Agni it then goes to Udana, Vyana, and Prana, thus providing its efficacy all over the body, at the same time Basti by pacifying Vata restores the disturbed Kapha and pitta at their Moolasthana and thus helps in the Samprapthi Vikhatana. Pharmacokinetic studies have also proved that drugs administrated via rectum can achieve higher blood levels of the drug than oral route due to partial avoidance of hepatic first-pass metabolism. The rectum has a rich blood and lymph supply and drugs can cross the rectal mucosa as they can other lipid membranes. Thus, un-ionized and lipidsoluble substances are readily absorbed from the rectum. The portion absorbed from the upper rectal mucosa is carried by the superior haemorrhoidal vein into the portal circulation, whereas that absorbed from the lower rectum enters directly into the systemic circulation via the middle and inferior haemorrhoidal veins. Thus, the administration of drugs in the Basti form has faster absorption and provides quicker results. The rectal wall contains neuron receptors and pressure receptors which are stimulated by various Basti Dravyas. Simulation results in an increase in the conduction of sodium ions. The inward rush of sodium ions through the membrane of the unmyelinated terminal is responsible for generating the action potential, an influx of ion thereby generating an action potential. The drugs, immediately after entering into the Pakwashaya (intestines), strike at the very root of vitiated Vata.

\section{CONCLUSION}

At the end of the study both the groups are having effect on reducing the symptoms statistically. Among the subjective and objective parameters, Group A showed better reduction $51.47 \%$ in Ruk, Sthambha, Toda, Gaurava, active and passive SLR test, Bragard's test and Lumbar movements. Group B does not have statistically significant over Gaurava, left lateral flexion and rotation to leave. Showed reduction $40.49 \%$ in Ruk, Sthambha, Toda active and passive SLR test and lumbar movement. Matra Basti with Vyosadi Tailam is having more effect on symptoms of Gridhrasi and shows long lasting result. Thus, the alternate hypothesis $\mathrm{H} 2$ is accepted i.e there is significant effect of Vyoshadi Taila Matra Basti over Sahacharadi Taila Matra Basti in the management of Gridrasi (sciatica). 


\section{REFERENCES}

1. Acharya $\mathrm{J} \mathrm{T}$, editor, $\left(2^{\text {nd }}\right.$ ed $)$. Commentary Ayurveda Deepika of Chakrapanidatta on Charaka Samhita of Agnivesha, Sidddhistana; Kalpana Siddhi: Chapter 1, Verse 38-40, Varanasi: Chaukhamba Orientalia, 2015; p-683.

2. Acharya $\mathrm{J} \mathrm{T}$, editor, $\left(2^{\text {nd }}\right.$ ed). Commentary Ayurveda Deepika of Chakrapanidatta on Charaka Samhita of Agnivesha, Sidddhistana; Kalpana Siddhi: Chapter 1, Verse 29, Varanasi: Chaukhamba orientalia, 2015; p682.

3. Acharya J T, editor, ( $2^{\text {nd }}$ ed). Commentary Nibandhasangraha of Dalhanacharya on Sushrutha samhitha of Sushrutha, Chikitsastana; Netra Basti Pramana Vibhaga Chikitsa: Chapter 35, Verse 18, Varanasi: Chaukhamba Orientalia, 2014; p- 701.

4. Acharya JT, editor, ( $2^{\text {nd }}$ ed), Commentary Ayurveda Deepika of Chakrapanidatta on Charaka Samhita of Agnivesha, Sidddhistana; Bastivyapat Siddhi Adyaya: Chapter 4, Verse 52-54, Varanasi: Chaukhamba orientalia, 2015; p-701.

5. Acharya JT, editor, ( $2^{\text {nd }}$ ed). Commentary Ayurveda Deepika of Chakrapanidatta on Charaka Samhita of Agnivesha, Sutra Stana; Maharogadhyaya: Chapter 20, Verse 11, Varanasi: Chaukhamba orientalia, 2015; p113.

6. Acharya JT, editor, ( $2^{\text {nd }}$ ed). Commentary Ayurveda Deepika of Chakrapanidatta on Charaka Samhita of Agnivesha, Chikitsa Sthana; Vatavyadhi Chikitsitam: Chapter 28, Verse 56-57, Varanasi: Chaukhamba orientalia, 2015; p-619.

7. Sir Stanley Davidson, Davidson's Principles and Practice of Medicine, editors Nicholas A Boon, Nicki R Colledge, Brian R Walker, John A.A Hunter, published by Churchill Livingstone Elsevier, 20th Edition (2006), 26th chapter, p. 1242.

8. http://en.m.wikipedia.org/wiki/Sciatica.

9. Acharya JT, editor ( $2^{\text {nd }}$ ed). Commentary Ayurveda Deepika of Chakrapanidatta on Charaka Samhita of Agnivesha, Chikitsa Sthana; Vatavyadhi Chikitsitam: Chapter 28, Verse 101, Varanasi: Chaukhamba orientalia, 2015; p-621.

10. Vaidya BHP, editor $\left(10^{\text {th }}\right.$ ed), Commentary Sarvangasundara of Arunadatta and Ayurvedarasayana of Hemadri on Astangahrdayam of Vagbhata; Chikitsa Sthana; Vatavyadhi Chikitsitam; Chapter 21, Verse 7072, Varanasi; Chaukhamba orientalia, 2014; p-727.
11. Tewari Premvati, Kumari Asha, editor ( $1^{\text {st }}$ ed) Vrindamadhava, Part 1; Vatadhikara; Chapter 20, Verse 227-230, Varanasi; Chaukhambha Visvabharati, 2006; p-341.

\section{Source of Support: Nil \\ Conflict of Interest: None Declared}

How to cite this URL: Vasudev R \& Swathi S Deshpande: A Comparative Clinical Study On Matra Basti With Sahacharadi Taila And Vyosadi Taila In Gridhrasi W.S.R To Sciatica. International Ayurvedic Medical Journal \{online\} 2020 \{cited October, 2020\} Available from: http://www.iamj.in/posts/images/upload/4694_4700.pdf 